\title{
POTENSI FERMENTABILITAS RUMINAL HIJAUAN PAKAN KAMBING
}

\author{
POTENTIAL RUMINAL FERMENTABILITYOF FORAGE FOR GOATS
}

\author{
Anggun Novi Barlian*, Marry Christiyanto*, Eko Pangestu*, Limbang Kustiawan \\ Nuswatara* \\ *Laboratorium Ilmu Nutrisi dan Pakan Fakultas Peternakan dan Pertanian Universitas \\ Diponegoro, Semarang \\ Alamat: Jl. Prof. H. Soedarto, S.H - Tembalang Semarang, Indonesia 50275 \\ *Email: Anggun.novi.b@gmail.com \\ Diterima: 24 februari 2020, Direvisi: 2 April 2020, Disetujui: 17 Mei 2020
}

\begin{abstract}
ABSTRAK
Penelitian ini bertujuan untuk mengkaji nilai fermentabilitas ruminal yaitu VFA total dan $\mathrm{NH}_{3}$ total hijauan pakan kambing. Manfaat dari penelitian ini dapat mengevaluasi fermentabilitas ruminal hijauan pakan kambing serta memudahkan dalam formulasi pakan yang efisien didasarkan dari produksi VFA dan $\mathrm{NH}_{3}$ dilakukan secara in vitro. Rancangan percobaan yang digunakan adalah rancangan acak kelompok (RAK) dengan perlakuan yaitu 7 jenis bahan pakan hijauan dan 3 kali pengambilan cairan rumen sebagai kelompok. Perlakuan meliputi: R1 = Daun Indigofera; R2 = Daun Insulin; R3 = Daun Jambu Biji; R4 = Daun Melinjo; R5 = Daun Rambutan; R6 = Daun Singkong; R7= Daun Waru. Hasil analisis menunjukkan produksi $\mathrm{NH}_{3}$ dari daun indigofera, daun insulin, daun jambu, daun melinjo, daun singkong dan daun waru sudah optimal untuk sintesis protein mikroba rumen. Produksi VFA pada daun indigofera, daun insulin, daun jambu, daun melinjo, daun rambutan dan daun singkong sudah dapat memenuhi untuk pertumbuhan mikroba rumen.
\end{abstract}

Kata kunci : Hijauan pakan, In Vitro, $\mathrm{VFA}, \mathrm{NH}_{3}$ dan fermentabilitas

\begin{abstract}
The goal of this experiment was to examine the value of ruminal fermentability that is total VFA and total NH3 of forages for goat. The benefits of this research were can help check the ruminal fermentability of forages for goat and help the efficient formulation of feed as seen from VFA and NH3 production carried out in vitro. The research was done in randomized block design $(R B D)$ with 7 types of forages as treatment and 3 rumen groups as replications. Treatment coverage: $R 1=$ Indigofera leaves; $R 2=$ Insulin leaves; $R 3=$ Guava leaves; $R 4=$ Melinjo leaves; $R 5=$ Rambutan Leaves; $R 6=$ Cassava Leaves; $R 7$ : Waru leaves. The result showed that production of NH3 in indigofera leaves, insulin leaves, guava leaves, melinjo leaves, cassava leaves, and waru leaves are optimal for rumen microbial protein synthesis. VFA production in indigofera leaves, insulin leaves, guava leaves, melinjo leaves, rambutan leaves, and cassava leaves can fulfill for rumen microbial growth.
\end{abstract}

Keywords: Forage, In Vitro, VFA, NH3 and fermentability

Potensi Fermentabilitas Ruminal Hijauan Pakan Kambing - Anggun Novi Barlian, Marry Christiyanto, Eko 


\section{PENDAHULUAN}

Pakan untuk ruminansia terdiri dari pakan hijauan sebagai pakan utama. Hijauan merupakan pakan kaya serat yang mempunyai sifat fisik bervariasi dan dapat berpengaruh terhadap tingkat konsumsi dan kecernaan ternak (Toharmat et al., 2010). Hijauan merupakan sumber serat, dan merupakan komponen terbesar (60$70 \%$ ) penyusun pakan kambing, walaupun energinya rendah (Suryani et al., 2014). Serat pakan dapat merangsang aktivitas mengunyah dan proses fermentasi di dalam rumen. Hijauan merupakan pakan kaya serat yang mempunyai sifat fisik yang bervariasi dan dapat berpengaruh terhadap tingkat konsumsi dan kecernaan ternak

Fermentabilitas bahan pakan dapat digambarkan oleh produksi amonia $\left(\mathrm{NH}_{3}\right)$ dan volatile fatty acids (VFA) total. Produksi amonia atau $\mathrm{NH}_{3}$ yang tinggi artinya banyak protein ransum yang mudah didegradasi oleh mikroba rumen, sedangkan produksi VFA total yang tinggi artinya banyak bahan organik ransum yang mudah didegradasi oleh mikroba rumen (Oktariani et. al., 2015). Asam lemak terbang atau VFA merupakan produk akhir fermentasi karbohidrat dan merupakan sumber energi utama bagi ruminansia (Puastuti, 2012). Karbohidrat merupakan faktor utama yang mempengaruhi penggunaan $\mathrm{NH}_{3}$ yang berfungsi sebagai sumber energi untuk pembentukan protein mikroba (Prayitno et al., 2018).

Penelitian ini bertujuan untuk mengkaji nilai fermentabilitas ruminal yaitu VFA dan amonia $\left(\mathrm{NH}_{3}\right)$ total hijauan pakan kambing. Manfaat dari penelitian ini dapat mengevaluasi fermentabilitas ruminal hijauan pakan kambing serta memudahkan dalam formulasi pakan yang efisien

\section{MATERI DAN METODE}

Penelitian ini dilakukan 2 tahap yang pertama yaitu penyiapan bahan pakan dan analisis proksimat berupa 7 hijauan pakan kambing yang dilaksanakan pada bulan Juni - September 2019. Tahap kedua, uji in vitro VFA dan $\mathrm{NH}_{3}$ yang dilaksanakan pada bulan Oktober Desember 2019. Penelitian dilakukan di Laboratorium Ilmu Nutrisi dan Pakan, Fakultas Peternakan dan Pertanian, Universitas Diponegoro, Semarang. Materi yang digunakan dalam penelitian adalah hijauan pakan kambing yaitu daun indigofera, daun insulin, daun jambu, daun melinjo, daun rambutan, daun singkong, dan daun waru. Pencernaan fermentatif (anaerob) di rumen, dilakukan dengan metode Tilley and Terry (1963). Analisis produksi $\mathrm{NH}_{3}$ dilakukan dengan menggunakan teknik mikrodifusi Conway (1950). Produksi $\mathrm{NH}_{3} \quad$ dihitung menggunakan rumus:

\section{$\mathrm{N}-\mathrm{NH}_{3}(\mathrm{Mm})=\mathrm{ml}$ titran $\times \mathrm{N}_{2} \mathrm{SO}_{4} \times$ 1000}

Keterangan:

$\mathrm{N}=$ normalitet $\mathrm{H}_{2} \mathrm{SO}_{4}$

Analisis produksi VFA dilakukan menggunakan metode destilasi uap. Produksi VFA dihitung menggunakan rumus:

VFA total $(\mathrm{nM})=\underset{1000 / 5}{(\mathbf{a}-\mathbf{b}) \times \mathrm{N}} \mathrm{HCl} \times$

Keterangan:

$\mathrm{N}=$ normalitet $\mathrm{HCl}$

$\mathrm{a}=\mathrm{ml}$ titran blanko

$\mathrm{b}=\mathrm{ml}$ titran

Rancangan percobaan yang digunakan adalah rancangan acak kelompok (RAK) dengan perlakuan 7 jenis bahan pakan hijauan dengan 3 kali pengambilan cairan rumen sebagai kelompok dengan $\mathrm{pH}$ berkisar 6,5 - 7 


\section{HASIL DAN PEMBAHASAN}

Hasil penelitian produksi VFA dan NH3 disajikan pada Tabel 1. Daun insulin menghasilkan produksi $\mathrm{NH}_{3}$ sebesar 6,00 $\mathrm{mM}$. Produksi $\mathrm{NH}_{3}$ daun insulin yang tinggi disebabkan kandungan protein kasar dari daun insulin sebesar 23,98 persen. Hal ini diduga kandungan protein pakan yang lebih mudah didegradasi oleh mikroba rumen, semakin tinggi kemampuan mikroba rumen mendegradasi protein, maka kadar $\mathrm{NH}_{3}$ juga tinggi. Hapsari et al. (2018) menjelaskan bahwa di dalam rumen, protein akan mengalami hidrolisis oleh aktivitas enzim mikroba menjadi peptida. Sebagian peptida kemudian digunakan untuk membentuk protein sel mikroba dan asam amino. Asam amino selanjutnya akan terdeaminasi menjadi $\mathrm{NH}_{3}$ oleh aktivitas mikroba sehingga kadar $\mathrm{NH}_{3}$ dalam rumen tergantung dari kandungan protein pakan.
Perhitungan analisis ragam menunjukkan bahwa jenis hijauan pakan memberikan perbedaan produksi $\mathrm{NH}_{3}$ $(\mathrm{P}<0,05)$. Hal ini disebabkan karena hijauan pakan yang berbeda memiliki kandungan nutrien bahan pakan yang berbeda pula terutama protein. Prayitno et al. (2018) menyatakan bahwa yang mempengaruhi produksi $\mathrm{NH}_{3}$ adalah kadar protein pakan, kelarutan/degradabilitas protein, dan ketersediaan karbohidrat dalam ransum yang berfungsi sebagai sumber energi untuk pembentukan protein mikroba. Keadaan rumen seperti jumlah mikroba dan $\mathrm{pH}$ rumen akan mempengaruhi produksi $\mathrm{NH}_{3}$ yang berbeda pada tiap kelompok. Hal ini sesuai dengan pendapat Purbowati et al. (2015) yang menyatakan menyatakan bahwa $\mathrm{pH}$ rumen merupakan salah satu faktor yang mempengaruhi populasi.

Tabel 1.

Produksi VFA dan NH3 Hijauan Pakan Kambing

\begin{tabular}{|c|c|c|}
\hline Perlakuan & $\mathrm{NH}_{3}$ & VFA \\
\hline & \multicolumn{2}{|c|}{ 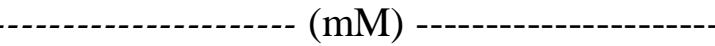 } \\
\hline Daun Indigofera & $5,03^{b}$ & $116,67^{\mathrm{a}}$ \\
\hline Daun Insulin & $6,0^{\mathrm{a}}$ & $110^{\mathrm{a}}$ \\
\hline Daun Jambu & $4,02^{c}$ & $96,67^{\mathrm{ab}}$ \\
\hline Daun Melinjo & $5,30^{\mathrm{ab}}$ & $80^{\mathrm{b}}$ \\
\hline Daun Rambutan & $3,28^{\mathrm{d}}$ & $80^{\mathrm{b}}$ \\
\hline Daun Singkong & $5,00^{\mathrm{bc}}$ & $76^{\mathrm{b}}$ \\
\hline Daun Waru & $3,76^{\mathrm{c}}$ & $69,33^{c}$ \\
\hline
\end{tabular}

Keterangan : Superskrip yang berbeda pada kolom yang sama menunjukkan perbedaan nyata $(\mathrm{P}<0,05$

Pengukuran $\mathrm{pH}$ cairan rumen kambing berkisar antara $6,5-7$ berarti kondisi rumen kambing pada semua kelompok berada pada suasana ideal bagi mikroba rumen. Hal ini sesuai dengan pendapat Kamra (2005) bahwa kondisi agar mikroba rumen agar dapat melakukan aktivitas optimal apabila $\mathrm{pH}$ rumen berada pada kisaran yaitu 6-6,9.
Uji Ganda Duncan menunjukkan bahwa produksi $\mathrm{NH}_{3}$ pada daun insulin tidak berbeda nyata $(\mathrm{P}>0,05)$ dengan daun melinjo. Produksi $\mathrm{NH}_{3}$ pada daun indigofera ada perbedaan $(\mathrm{P}<0,05)$ produksi $\mathrm{NH}_{3}$ dibandingkan dengan daun insulin, daun jambu, daun singkong dan daun waru. Produksi $\mathrm{NH}_{3}$ daun jambu tidak berbeda nyata $(\mathrm{P}>0,05$ dengan daun 
waru dan daun singkong. Daun rambutan menunjukkan perbedaan $(\mathrm{P}<0,05)$ produksi $\mathrm{NH}_{3}$ dengan semua perlakuan hijauan pakan kambing. Produksi $\mathrm{NH}_{3}$ pada daun rambutan sebesar 3,28 mM. Produksi $\mathrm{NH}_{3}$ yang rendah dikarenakan kandungan protein daun rambutan $(8,67 \%)$ yang lebih rendah dibandingkan perlakuan lainnya dan memungkinkan protein tidak didegradasi oleh mikroba rumen secara optimal. Ariantika et al. (2015) berpendapat bahwa apabila kandungan protein kasar rendah atau proteinnya tahan terhadap degradasi mikroba rumen maka konsentrasi amonia $\left(\mathrm{NH}_{3}\right)$ rumen akan rendah dan pertumbuhan mikroba rumen lambat. Efisiensi sintesis protein mikroba yang maksimal dipengaruhi dari ketersediaan $\mathrm{N}$ dan energi di dalam rumen yang seimbang. Produk $\mathrm{NH}_{3}$ di dalam rumen akan dimanfaatkan oleh mikroba rumen untuk sintesis tubuhnya. Suryani et al. (2014) menyatakan bahwa, untuk memperoleh efisiensi sintesis protein mikroba yang maksimal, maka ketersediaan $\mathrm{N}$ dan energi di dalam rumen harus seimbang. Keseimbangan ini akan diperoleh dengan pemberian pakan yang cermat dengan memperhitungkan hijauan sebagai sumber protein dan sumber energi.

Daun Indigofera menghasilkan produksi VFA sebesar 116,67 $\mathrm{mM}$. Produksi VFA perlakuan daun indigofera tinggi disebabkan karena daun indigofera memiliki kandungan karbohidrat sebesar 75,08 persen. Nilai tersebut tergolong besar, sehingga tingginya produksi VFA dipengaruhi oleh kandungan karbohidrat pada pakan dan VFA diperoleh dari hasil fermentasi sebagian besar karbohidrat. Hal ini sesuai dengan pendapat Nurhaita, et al (2020) yang menyatakan bahwa VFA dipengaruhi kandungan serat, komponen serat pada pakan antara lain selulosa, hemiselulosa, lignin, pati dan karbohidrat yang larut dalam air selanjutnya, selulosa dan pati didegradasi menjadi asam piruvat dan kemudian difermentasi kembali oleh mikroba menjadi VFA. Hapsari, et al. (2018) menambahkan bahwa konsentrasi VFA total yang tinggi menggambarkan banyaknya bahan organik ransum yang mudah didegradasi oleh mikroba rumen. Konsentrasi VFA yang tinggi berkaitan dengan $\mathrm{pH}$ rumen yang berada dalam keadaan seimbang sehingga mikroba rumen mampu bekerja dengan baik dalam proses fermentasi sehingga produksi VFA total menjadi optimal. Hasil analisis ragam menunjukkan bahwa perbedaan jenis hijauan pakan memberikan perbedaan produksi VFA $(\mathrm{P}<0,05)$. Hal ini disebabkan karena perbedaan kandungan nutrien tiap bahan yang dapat dicerna dan difermentasi. Ariantika (2015) menyatakan bahwa tinggi rendahnya produksi VFA disebabkan karena jumlah nutrisi, kadar protein dan fermentabilitas pakan.

Data Tabel 1 menunjukkan bahwa produksi VFA pada daun indigofera tidak berbeda nyata $(\mathrm{P}>0,05)$ dengan daun melinjo dan daun rambutan. Produksi VFA pada daun insulin dan daun singkong tidak ditemukan perbedaan $(\mathrm{P}>0,05)$ dan daun waru menujukkan perbedaan $(\mathrm{P}<0,05)$ produksi VFA dengan perlakuan lainnya. Produksi VFA terendah 69,33 $\mathrm{mM}$ diperoleh pada perlakuan daun waru dengan kandungan karbohidrat sebesar $68,68 \%$ lebih tinggi jika dibandingkan dengan daun Insulin dimana kandungan karbohidrat sebesar $53,55 \%$ dan produksi VFA sebesar $80 \mathrm{mM}$. Hal ini diakibatkan karena VFA diperoleh dari hasil fermentasi sebagian besar karbohidrat dan sebagian kecil protein agar populasi mikroba rumen maksimal untuk memproduksi VFA, pada daun waru kandungan protein kasar lebih rendah $(12,55 \%)$ dibandingkan dengan daun insulin $(23,98 \%)$ sehingga populasi mikroba rumen tidak maksimal dan rendahnya produksi VFA pada daun waru. 
Hal ini sesuai dengan pendapat Morvay et al. (2011) bahwa komposisi VFA yang terbentuk di dalam rumen dipengaruhi oleh substrat yang difermentasi, populasi mikroba dan ekologi rumen. Muchlas et al. (2014) menambahkan faktor yang mempengaruhi produksi VFA antara lain jenis mikroba, penyerapan dan fermentabilitas dari pakan sumber karbohidrat. Volatile Fatty Acids adalah produk akhir hasil fermntasi dan digunakan sebagai sumber energi. Hal ini sesuai dengan pendapat Agematu, et al. (2017) yang menyatakan bahwa VFA sebenarnya dianggap sebagai produk limbah bakteri namun, ruminan menyerap dan menggunakannya sebagai sumber energi utama.

\section{KESIMPULAN}

Berdasarkan hasil penelitian disimpulkan bahwa (hijauan pakan kambing yang berbeda menghasilkan) produksi $\mathrm{NH}_{3}$ dan VFA yang berbeda. Produksi $\mathrm{NH}_{3}$ paling tinggi yaitu daun insulin Produksi $\mathrm{NH}_{3}$ yang tinggi dikarenakan kandungan protein hijauan tinggi sehingga akan mempengaruhi degradasi protein. Produksi VFA paling tinggi pada indigofera yaitu daun indigofera, produksi VFA yang tinggi karena komponen serat tinggi seperti selulosa, hemiselulosa, lignin, pati dan karbohidrat yang larut dalam air. Komponen tersebut didegradasi menjadi asam piruvat dan kemudian difermentasi kembali oleh mikroba. 


\section{DAFTAR PUSTAKA}

Agematu, H., T. Takahashi and Y. Hamano. 2017. Continuous volatile fatty acid production from lignocellulosic biomass by a novel rumen-mimetic bioprocess. Journal of bioscience and bioengineering. 124 (5): 528-533.

Ariantika, S. R. A., A. Rochana dan B. Ayuningsih. 2015. Pengaruh pemberian ransum berbasis pelepah dan daun kelapa sawit terhadap konsentrasi VFA dan NH3 cairan rumen sapi $\mathrm{FH}$ jantan (In Vitro). Journal E-Student. 4 (1): 1-11

Conway, E.J. 1950. Microdiffusion Analysis and Volumetric Error. $2^{\text {nd }}$ Ed. Crosbay and Lockwood, London.

Hapsari, N. S., D. W. Harjanti dan A. Muktiani. 2018. Fermentabilitas pakan dengan imbuhan ekstrak daun Babadotan (Ageratum conyzoides) dan Jahe (Zingiber officinale) pada sapi perah secara in vitro. Jurnal Agripet. 18 (1), 1-9.

Kamra, D. N. 2005. Rumen microbial ecosystem. Special Section: Microbial Diversity. Current Science. 89 (1) : 124 - 135

Morvay, Y., A. Bannink, J. France, E. Kebreab J. and Dijkstra, J. 2011. Evaluation of models to predict the stoichiometry of volatile fatty acid profiles in rumen fluid of lactating Holstein cows. J. Dairy Sci. 94 (6): 3063-3080.

Muchlas, M., K. Kusmartono dan M. Marjuki. 2014. Pengaruh penambahan daun pohon terhadap kadar VFA dan kecernaan secara in-vitro ransum berbasis ketela pohon. $\mathrm{J}$. Ilmu-Ilmu Peternakan. 24 (2): 8-19.

Nurhaita, N., N. Definiati dan N. Hidayah. 2020. Karakteristik fermentabilitas dalam rumen in vitro pada Pelepah Sawit fermentasi yang disuple- mentasi tepung Kulit Jengkol. Jurnal Peternakan. 17(1): 39-44.

Oktariani, N., T. Dhalika dan A. Budiman. 2015. Pengaruh penambahan nitrogen dan sulfur pada ensilase jerami ubi jalar (Ipomea batatas L.) terhadap konsentrasi $\mathrm{NH}_{3}$ dan VFA (In vitro). Students EJournals. 4 (3): $15-20$.

Prayitno, R. S., F. Wahyono dan E. Pangestu. 2018. Pengaruh suplementasi sumber protein hijauan leguminosa terhadap produksi amonia dan protein total ruminal secara In Vitro. J. Peternakan Indonesia. 20 (2): 116 $-123$.

Puastuti, W., D. Yulistiani dan I.W. Mathius. 2012. Respon fermentasi rumen dan retensi nitrogen dari domba yang diberi protein tahan degradasi dalam rumen. JITV. 17 (1): $67-72$.

Purbowati, E., I. Rahmawati dan E. Rianto. 2015. Jenis hijauan pakan dan kecukupan nutrien kambing jawarandu di Kabupaten Brebes Jawa Tengah. Pastura. 5 (1): 10-14

Suryani, N. N., I. K. M. Budiasa dan I. P. A. Astawa. 2014. Fermentasi rumen dan sintesis protein mikroba kambing peranakan ettawa yang diberi pakan dengan komposisi hijauan beragam dan level konsentrat berbeda. Majalah Ilmiah Peternakan. 17 (2):56 - 60

Tilley, J.M.A. dan R. A. Terry. 1963. A two stage technique for the in vitro digestion of forage crops. J. British Grass. Soc. 18: 104 - 111.

Toharmat, T., E. Nursasih, R. Nazilah, N. Hotimah, T. Q. Noerzihad, N. A. Sigit dan Y. Retnani. 2010. Sifat fisik pakan kaya serat dan pengaruhnya terhadap konsumsi. J. Media Peternakan. 29 (3): 146 154. 